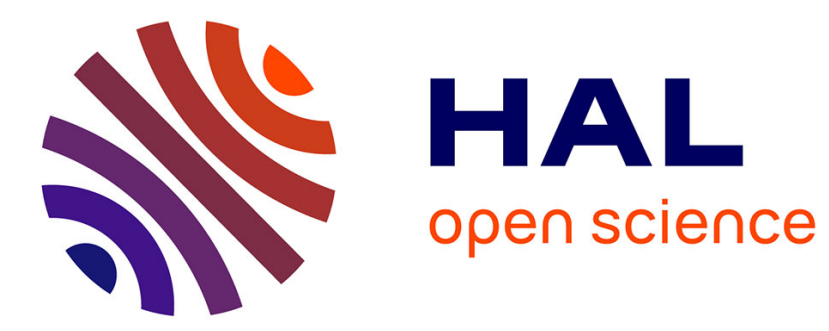

\title{
The transmission of business cycles: Lessons from the 2004 enlargement of the EU and the adoption of the euro
}

\author{
Hoang Sang Nguyen, Fabien Rondeau
}

\section{To cite this version:}

Hoang Sang Nguyen, Fabien Rondeau. The transmission of business cycles: Lessons from the 2004 enlargement of the EU and the adoption of the euro. Economics of Transition and Institutional Change, 2019, 27 (3), pp.729-743. 10.1111/ecot.12212 . hal-02440515

\section{HAL Id: hal-02440515 \\ https://hal.science/hal-02440515}

Submitted on 15 Jan 2020

HAL is a multi-disciplinary open access archive for the deposit and dissemination of scientific research documents, whether they are published or not. The documents may come from teaching and research institutions in France or abroad, or from public or private research centers.
L'archive ouverte pluridisciplinaire HAL, est destinée au dépôt et à la diffusion de documents scientifiques de niveau recherche, publiés ou non, émanant des établissements d'enseignement et de recherche français ou étrangers, des laboratoires publics ou privés. 


\title{
The Transmission of Business Cycles: Lessons From the 2004 Enlargement and the Euro Adoption
}

\author{
Hoang Sang Nguyen \\ CREM UMR CNRS 6211-University of Rennes 1 \\ Fabien Rondeau ${ }^{1}$ \\ CREM UMR CNRS 6211-University of Rennes 1
}

\begin{abstract}
This paper evaluates macroeconomic interdependencies of seven Central and Eastern European Countries (CEECs) with the Euro Area (EA) through trade relationship. We estimate a near-VAR model and we simulate responses of activity in those CEECs to output shocks for twelve former members of the EA before and after the 2004 enlargement of the European Union (EU). During both periods, empirical results show that spillover effects come through the main economies of the EA: Germany, France and Italy. Furthermore, CEECs are more responsive to output shocks in the EA after 2004 than before (3.3 times larger on average). Increases in spillover effects are larger for the three CEECs that adopted the Euro early (Slovenia, Slovakia, and Estonia) than the other CEECs (4.9 versus 2.1) but without higher trade intensity with the EA (1.07 versus 1.12). Our results show that trade effects are positive inside the same currency area but negative for the CEECs without the euro.
\end{abstract}

JEL Classifications: F13, F15, F45

Keywords: Enlargement, European Union, Trade Spillovers, Euro, Near-VAR, OCA

1 Corresponding author: fabien.rondeau@univ-rennes1.fr, 7 place Hoche 35000 Rennes, France. Tel. +33223233366. The authors are very grateful to Graham Gerein, Jason Garred, Isabelle Cadoret, JeanSébastien Pentecôte, Sébastien Pommier, and participants of the 18th annual conference of ETSG for their helpful comments. This project benefited from financial support of the research funding program "Emerging scientific issues" of the University of Rennes 1 and of the CREM-CNRS research center.

The authors are also very grateful to an anonymous reviewer and to two editors. 


\section{Introduction}

Business cycle transmission is a key issue specifically in the context of monetary integration. Large spillover effects can dampen asymmetric shocks and increase business cycle synchronization. This is a particular issue for Central and Eastern European Countries (CEECs) after the Treaty of Accession ${ }^{2}$ with the European Union (EU), on 1 May 2004. Some of these new member states have since adopted the Euro: Slovenia (2007), Cyprus and Malta (2008), Slovakia (2009), Estonia (2011), Latvia (2014) and Lithuania (2015), while their neighbours did not yet. One may thus ask whether these divergent attitudes towards European monetary integration had any impact on their ability to limit output losses from excessive business fluctuations.

As stated by the Optimum Currency Area theory (OCA, Mundell, 1961) countries with a high degree of business cycle synchronization may find it optimal to adopt a common currency. In this case, the costs of monetary integration are lower than the benefits. For McKinnon (1963) and Kenen, (1969), trade integration reduces exposure of countries to asymmetric shocks, and so reduces costs of currency unification. A large literature confirms the positive effects of trade on business cycle synchronization (Clark and van Wincoop, 2001, Imbs, 2004, Baxter and Kouparitsas, 2003, 2005, Dées and Zorell, 2012, Gouveia and Correia, 2013, among others). Even if trade integration is not large enough before monetary integration, an endogeneity effect of OCA can occur: the monetary unification increases trade ex post and so synchronization (Frankel and Rose, 1998). However, for Krugman (1993), trade integration should increase sectoral specialization and asymmetric shocks.

\footnotetext{
2 This included eight Central and Eastern European countries (the Czech Republic, Estonia, Hungary, Latvia, Lithuania, Poland, Slovakia, and Slovenia), and two Mediterranean countries (Malta and Cyprus).
} 
This paper focuses on business cycle transmission from the Euro Area (EA) to the CEECs. We evaluate the responses of CEECs (CEECs-7) to an industrial production shock originating from the twelve initial members of the EA (EA-12) and we investigate how CEECs that have adopted the euro react differently to EA shocks than the other CEECs countries. We relate these responses to changes of trade intensity with the EA. Two main results emerge from this study: first, we find that Slovenia, Slovakia and Estonia, three CEECs using the euro, react more strongly to the output shock from the EA economies. Second, those changes in economic integration are not correlated with trade intensity with the EA. CEECs using the euro are more sensitive to the EU shocks even if changes of their trade intensity to the EA are the same as the other CEECs. In other words, adopting the euro does not increase trade intensity but magnifies the effects of trade spillover. Spillover effects of trade are positive within the same currency area (from the EA to Slovenia, Slovakia and Estonia) but not between two currency areas (from the EA to the Czech Republic, Hungary, Lithuania, and Poland).

The paper is structured as follows. The first section reviews the main studies concerning integration of the CEECs into the EU. The second section describes the econometric methodology, and the required data. The third section describes and assesses the empirical results: $i$ ) the effects of the 2004 Enlargement on spillovers, ii) the origins of the spillovers, and iii) the effects of the Euro on spillovers. The final section presents the conclusion.

\section{Literature Review}

Beginning in the late 1990s, several studies tried to evaluate the degree of business cycle synchronization between CEECs and the EA (see Fidrmuc and Korhonen, 2006, for a survey). Most of those studies found a different level of integration between CEECs. Boone and Maurel (1999) found that CEECs' economic cycles were close enough to those of the EU for a monetary 
union. And this was particularly the case for Hungary, Poland and Slovakia. For Fidrmuc and Korhonen (2003), only Hungary exhibits a high degree of business cycle correlations with EA. Korhonen (2003) showed that EU shocks could explain a large part of business cycles in Hungary and in Slovenia. But smaller CEECs are less sensitive to EA shocks. For Fidrmuc and Korhonen (2006), "Many new EU member states have achieved a relatively high degree of business cycle correlation with the euro area. This seems to be especially true for Hungary, Poland and Slovenia ». After the 2004 enlargement, Artis et al. (2008) found that the business cycles of Hungary, Slovenia and Poland run parallel to the business cycle of the euro. JimenezRodriguez et al. (2010) use a near-VAR model to investigate the impact of interest rate, commodity price and industrial production shocks on key macroeconomic variables for ten CEECs over the period from the early 1990s to 2009. They suggest that some countries like Slovakia and Slovenia - already euro area members - react more strongly to foreign industrial production shocks than other countries. In another study (Jimenez-Rodriguez et al., 2013), these authors find the same result: Slovakia and Slovenia exhibit a high degree of concordance with the European business cycle. The degree of concordance is similar to that of the Netherlands or Spain. Siedschlag (2010) analysed a sample of 171 pairs of countries of the Eurozone and CEECs over the period 1990-2003. Her empirical findings suggest that bilateral trade increases the similarity of business cycles. The IMF's spillover report $(2012, \mathrm{p} .6)$ indicated a positive relationship between real output in the EA and GDP fluctuations in Central, Eastern and Southeastern Europe regions via trade channels. Stanisic (2013) studied co-movements of the CEECs' GDPs and showed that there is no common business cycle between CEECs, although a synchronization trend is obvious with the EA. Keppel and Prettner (2015) developed a theoretical framework based on the structural vector error correction model to assess the effects of shocks to output, interest rates, exchange rate and relative prices on the EA and CEECs. Their 
results show strong inter-regional spillovers of output shocks. Recently, Di Giorgio (2016), using a Markov switching auto-regressive model, has rejected the hypothesis of the independence of CEECs' cycles from the EA cycle.

\section{Model Specification and Data}

A near-VAR model is exploited to take into account the degree of trade integration (the econometric strategy is similar to Abeysinghe and Forbes, 2005, and Dungey et al., 2018). This near-VAR model allows us to capture both the direct and indirect spillover effects of trade.

Considering a sample with $n$ economies, which interact through bilateral trade relationships, the output of a country $i$ can be decomposed in the following way:

$$
Y_{i}=A_{i}+\sum_{j=1}^{n-1} X_{i j}-M_{i} \text { with }(\mathrm{j} \neq \mathrm{i})
$$

whith $Y_{i}$ denoting output of country $i, A_{i}$ being domestic demand, $M_{i}$ referring to import of country $i$ and $X_{i j}$ to export from country $i$ to country $j$.

Let us assume that domestic demand and imports depend on domestic output $\left(A_{i}=\right.$ $A_{i}\left(Y_{i}\right)$ and $M_{i}=M_{i}\left(Y_{i}\right)$ where $0<\frac{\partial A_{i}}{\partial Y_{i}}<1$ and $\left.0<\frac{\partial M_{i}}{\partial Y_{i}}<1\right)$, and that exports from country $i$ to country $j$ in the short run depend on country $j$ 's output $\left(X_{i j}=X_{i j}\left(Y_{j}\right)\right.$ where $\left.\frac{\partial X_{i j}}{\partial Y_{j}} \geq 0\right)$. Then equation (1) can be expressed in terms of growth rates as:

$$
\frac{\Delta Y_{i}}{Y_{i}}=a_{i} \varepsilon_{Y_{i}}^{A_{i}} \frac{\Delta Y_{i}}{Y_{i}}+\sum_{j=1}^{n} \theta_{i j} x_{i} \varepsilon_{Y_{j}}^{X_{i j}} \frac{\Delta Y_{j}}{Y_{j}}-m_{i} \varepsilon_{Y_{i}}^{M_{i}} \frac{\Delta Y_{i}}{Y_{i}}
$$

where $a_{i}=\frac{A_{i}}{Y_{i}}, \theta_{i j}=\frac{X_{i j}}{X_{i}}, x_{i}=\frac{X_{i}}{Y_{i}}, m_{i}=\frac{M_{i}}{Y_{i}}$ and $\varepsilon_{H}^{G}$ refers to the elasticity of variable $G$ with respect to $H$. 
Assuming also that each country $i$ has the same elasticity of exports with respect to foreign activities for all countries $j$, we have $\varepsilon_{Y_{j}}^{X_{i j}}=\varepsilon_{Y_{i}^{e}}^{X_{i}}$ where $Y_{i}^{e}$ is the international demand of country $i$ 's goods. Under these assumptions, equation (2) can be re-written as follows:

$$
\frac{\Delta Y_{i}}{Y_{i}}=a_{i} \varepsilon_{Y_{i}}^{A_{i}} \frac{\Delta Y_{i}}{Y_{i}}+\sum_{j=1}^{n} \theta_{i j} x_{i} \varepsilon_{Y_{i}^{e}}^{X_{i}} \frac{\Delta Y_{j}}{Y_{j}}-m_{i} \varepsilon_{Y_{i}}^{M_{i}} \frac{\Delta Y_{i}}{Y_{i}}
$$

Finally, using small letters for growth rates:

$$
y_{i}=\beta_{i} y_{i}^{e}
$$

where $y_{i}=\frac{\Delta Y_{i}}{Y_{i}}, \beta_{i}=\frac{x_{i} \varepsilon_{Y_{i}^{e}}^{X_{i}}}{1-a_{i} \varepsilon_{Y_{i}}^{A_{i}}+m_{i} \varepsilon_{Y_{i}}^{M_{i}}}$ and $y_{i}^{e}=\sum_{j=1}^{n} \theta_{i j} y_{j}(\mathrm{j} \neq \mathrm{i})$.

Equation (3) constitutes a theoretical framework that will provide the bases for the development of a constrained VAR model to estimate the transmission of shocks.

Our model (3) is rewritten as a dynamic equation capturing both the adjustment of domestic GDP of country $i$ and the response of exports from country $i$ to country $j$ to fluctuations in the country $j$ 's output:

$$
g_{i}(L) y_{i, t}=h_{i}(L) y_{i, t}^{e}+u_{i, t}(4)
$$

where, $g_{i}(L)=1-g_{i, 1} L-\cdots-g_{i, P_{i}} L^{P_{i}}, h_{i}(L)=h_{i, 0}+h_{i, 1} L+\cdots+h_{i, q_{i}} L^{q_{i}}, i=1, \ldots n$ and $u_{i, t}$ is a residual term.

Using a matrix form including equations for all countries, the model can be written as follows:

$$
G(L) Y_{t}=H(L) Y_{t}^{e}+U_{t}=H(L) \Theta Y_{t}+U_{t}
$$




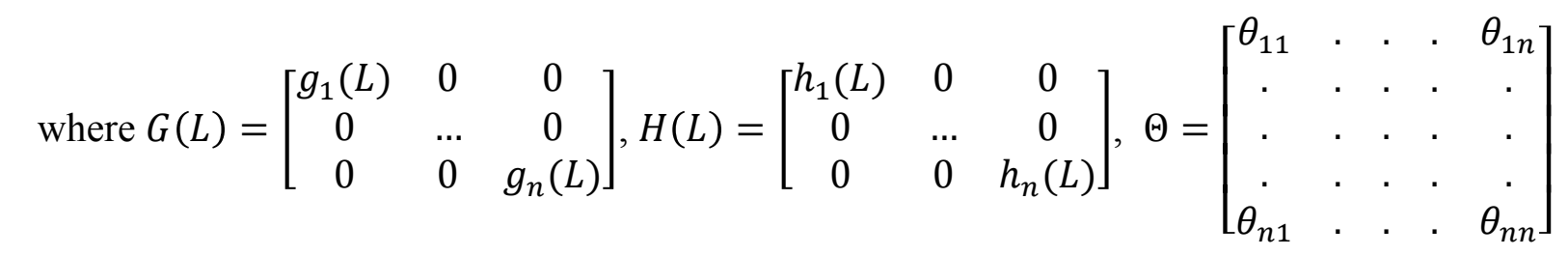
$Y_{t}=\left(y_{1, t}, \ldots, y_{n, t}\right)^{\prime}, Y_{t}^{e}=\left(y_{1, t}^{e}, \ldots, y_{n, t}^{e}\right)^{\prime}$ and $U_{t}=\left(u_{1, t}, \ldots, u_{n, t}\right)^{\prime}$.

The constrained VAR model is finally determined by imposing $n(n-2)$ restrictions on each coefficient matrix of the VAR model:

$$
\emptyset(L) Y_{t}=U_{t}
$$

where $\emptyset(L)=G(L)-H(L) \Theta, \emptyset(L)=\emptyset_{0}-\emptyset_{1} L-\ldots-\emptyset_{p} L^{p}$, and $p=\max \left(p^{i}, q^{i}\right)$. Entries of the matrix $\emptyset(L)$ are given by $\phi_{i j}(L)=-h_{i}(L) \theta_{i j}$ for $i, j=1,2, \ldots, n$ and $i \neq j$ and by $\phi_{i i}(L)=g_{i}(L)$ for $i=1, \ldots, n$.

The impulse response functions are computed from the VMA form of the model:

$$
Y_{t}=\emptyset^{-1}(L) U_{t}=\Psi(L) U_{t}
$$

where $\Psi(L)=\Psi_{0}+\Psi_{1} L+\ldots$ and $\Psi_{k,(i, j)}=\frac{\partial y_{i, t+k}}{\partial u_{j, t}}$.

The matrix of cumulative multiplier effects over $h$ periods in response to an innovation of output is then obtained by:

$$
M h=\sum_{s=1}^{h} \Psi_{s}
$$

From this model, we evaluate responses of seven CEECs to output shocks in the twelve initial members of the Euro area. We use the cumulative multiplier effects given by equation (7) to evaluate how CEECs are exposed to output fluctuations in the Euro area. This model includes all bilateral trade relationships between members of the Euro area and CEECs and therefore captures the direct and indirect transmissions of shocks. For example, an output shock to 
Germany not only impacts the GDP of Poland via direct bilateral trade between these two countries, but also spills over to Poland by influencing the economic activity elsewhere via bilateral trade between Germany and these third countries.

The sample consists of seven CEECs - the Czech Republic, Estonia, Hungary, Lithuania, Poland, Slovakia and Slovenia (CEECs-7) and the twelve founding members of the Euro area Austria, Belgium, Finland, France, Germany, Greece, Ireland, Luxembourg, the Netherlands, Italy, Portugal, and Spain (EA-12) - from January 1996 to September 2015. The choice of the sample is based on data availability. The monthly industrial production index (IPI) is used as a proxy for economic activity (data come from the OECD database and DataStream). The growth rate is given by the first difference of the logarithm of the IPI. Dickey-Fuller tests indicate that these series are stationary. ${ }^{3}$ The bilateral export share is the average of annual data over the studied period, and exports are extracted from the World Integrated Trade Solution database. To capture economic fluctuations in the rest of the world, we also introduce an exogenous variable computed as the export share-weighted output of the main economies: China, Japan, South Korea and India in Asia; United States, Canada, Brazil and Mexico in America and Russia, Denmark, Norway, Sweden and United Kingdom in Europe. This is done for each equation of the model. In this way, we capture from $75 \%$ (Slovenia) to $91 \%$ (Slovakia) of the total exports of the CEECs-7 economies.

Lag length selection is based on Akaike's Information Criterion (AIC) for each specific variable in the model. Lags cannot exceed twelve months. ${ }^{4}$ The Jarque-Berra tests and LjungBox tests are run to check for the normality and the non auto-correlation of residuals,

\footnotetext{
${ }^{3}$ Results are available upon request.

${ }^{4} \mathrm{We}$ also tried to estimate the model based on the Bayesian Information Criterion (BIC) with fixed or varying lags of specific variables. However, these models seem to be less efficient according to our data. Results are available upon request.
} 
respectively. Lag lengths are then adjusted to correct for the residual auto-correlation issue. Because lag lengths in each equation of the system are different and because exogenous variables are given by output variables weighted by trade shares, the model is estimated by the Seemingly Unrelated Regressions (SUR) method rather than Ordinary Least Squares (OLS).

We first begin by estimating the model over the period from January 1996 to September 2015. While the assumption of non auto-correlation of residuals is satisfied for all countries, residuals are normally distributed only in the equations of Germany, the Netherlands, Portugal and Italy (see Table A.1 in the online supplementary information).

We then perform Chow tests in order to determine whether structural breaks of coefficients exist in May 2004. The trade spillover effects from the Euro area to CEECs are expected to change after the largest enlargement of the European Union. As shown in Table A.2 (online supplementary information), only the estimated coefficients for Estonia and Poland are not significantly constant over time. However, Jiménez-Rodríguez et al. (2010), using the method proposed by Wang and Zivot (2000) to detect multiple structural breaks in industrial production of CEECs from 1990 to 2009, find significant breaks around 2004 (in August 2005 for Poland, in February 2002 for Estonia, in November 2003 for the Czech Republic, in January 2004 for Slovakia and in August 2001 for Slovenia). These results support our intuition that the model should be estimated on two sub-periods: pre- and post-accession. Furthermore, we perform many Chow tests for the introduction of the euro: January 2001 for Greece and January 1999 for other founding members of the Euro area; the dates that Slovenia, Slovakia, and Estonia switched to the euro in January 2007, January 2009, and January 2011, respectively; September to December 2008 for the Global Financial Crisis in 2008-09; and finally the sovereign debt crisis in Europe in September 2012. Results in Table A.2 reveal that the null hypothesis of no structural break cannot be rejected for all tested dates (except for Italy in 2008). 
We therefore estimate the near-VAR model over two sub-periods: from January 1996 to April 2004 and from May 2004 to September 2015. All of the series of residuals are not autocorrelated according to the Ljung-Box test. The normal distribution assumption is not statistically rejected in most of those economies. One of the most important tests in the VAR model is the cross-correlation of residuals test. The matrix of cross-correlations of residuals is presented in Table A.3 (online supplementary information). Only $4 \%$ of correlations are greater than $30 \%$ in the pre-accession model. This number shrinks to $2.3 \%$ during the post-accession period.

The hypothesis of non-correlation of residuals is tested by the Breusch-Pagan procedure: $\lambda=n \sum_{k=1}^{n} \rho_{k}$ where $\rho_{k}$ are correlations in ascending order, $\lambda$ follows a Chi-squared distribution and $1 \leq n \leq 171$ (since the maximum number of correlations in a model using 19 dependent variables is 171). Results of the performed tests for all values of $n$ indicate that only $11 \%$ of correlations are significantly different from zero for both pre- and post-accession models.

\section{Trade Spillovers From the EA to CEECs}

\section{1) Effects of the 2004 Enlargement on spillovers}

Running estimation of the near-VAR model on the two sub-periods, before and after the accession, allows us to compare the impulse responses of seven CEECs when facing an output shock of one standard error in the twelve initial members of the Euro area. We calculate the multiplier effects as cumulative impulse responses over 24 months (M24, see equ.7) and report these in Table A.4. We also build error bands of $16 \%$ and $84 \%$ as suggested by Sims and Zha 
(1999) from 5,000 Monte Carlo simulations. Results reveal that cumulative impulse responses are statistically different from zero. ${ }^{5}$

Three conclusions can be drawn from these results. Firstly, all impulse responses of CEECs are positive in both periods. This result indicates that the model captures the transmission of demand shocks. During the pre-accession period, we obtain a maximum multiplier effect of $1.71 \%$ when Lithuania adjusts to an output shock in Germany and a minimum of $0.03 \%$ when the Czech Republic reacts to a shock in Finland. Furthermore, whereas variations in growth of industrial production of CEECs converge to zero after 8 to 10 months during the pre-accession period, reactions are more persistent following the enlargement. Effects remain significant, on average, up to 20 to 24 months during this period.

Secondly, multiplier effects increase in the period following the enlargement of the European Union and are consistently correlated with trade intensity. Table 1 reports the changes in multiplier effects and in trade intensities: $\mathrm{R}_{\mathrm{M} 24}$ denotes the ratio of estimated multiplier effects during the post-accession period over multiplier effects during the pre-accession period, or more formally: $\mathrm{R}_{\mathrm{M} 24}=\mathrm{M} 24$ (post-accession)/M24(pre-accession). Trade intensity is calculated as $T I_{i j}=\frac{X_{i j}+I M_{i j}}{Y_{i}}$ where $X_{i j}$ is the average of exports of country $i$ to country $j$ over the sample period, $I M_{i j}$ is the average of imports of country $i$ from country $j$, and $Y_{i}$ is the average of output of country $i$. This trade intensity variable represents the share of bilateral trade with country $j$ in output and measures the degree of trade integration of country $i$ with country $j$. Similar to $\mathrm{R}_{\mathrm{M} 24}$, $\mathrm{R}_{\mathrm{TI}}$ in Table 1 measures changes in trade intensity between each CEEC with the Euro area members after/before the enlargement.

\footnotetext{
5 Results are available upon request.
} 


\section{INSERT TABLE 1 HERE}

In comparison with the pre-accession period, the Czech Republic, Estonia, Poland, Slovakia, and Slovenia significantly enhance their macroeconomic integration with the Euro area. These economies react more strongly and persistently to the economic fluctuations in the monetary union after becoming European Union members than before. All $\mathrm{R}_{\mathrm{M} 24}$ of these countries are greater than 1 . The biggest rise is 14.44 fold and concerns the 24-month ahead cumulated responses of Slovakia to an output shock in Finland. Lithuania responds more strongly to an output shock in Germany, the Netherlands, Spain and Finland. However, trade spillover effects from France to this economy did not change. Moreover, multiplier effects decrease when facing a shock in other EA-12 members. Also, Hungary reacts more strongly to a shock to the major countries in the Euro area such as Germany, the Netherlands, Spain, France, Italia and Finland. Multiplier effects decrease when output shocks occur in other EA-12 economies.

The results in Table 1 also reveal that most of the changes in multiplier effects are correlated with changes in trade intensity. Less than $24 \%$ of pairs (reported in italics) combine a value of $R_{M 24}$ higher than one and a $R_{T I}$ value lower than one. These cases mainly occur for Estonia and Lithuania and could be explained by larger indirect trade contagion than direct trade contagion. According to Table 1, it seems that the increase in trade intensity after the accession in European Union significantly increases trade spillover effects. The last column of Table 1 presents correlations between changes in the multiplier effect and changes in trade intensity. Except for shocks in Belgium, Italy and the Netherlands, correlations are positive and range from 0.16 to 0.65 . These results indicate that the CEECs- 7 are generally more affected by the EA-12 
countries' shocks since 2004 and this greater responsiveness is correlated with the increase in trade openness.

\section{2) The Origins of the spillovers}

We question which economies from the EA-12 most significantly influence CEECs in both the pre-accession and post-accession period. To this end, we compute a GDP-weighted multiplier effect as follows:

$$
\widetilde{R_{M 24 J}}=\frac{\widetilde{W M 24}}{W M 24}
$$

where $W M 24=\sum_{i=1}^{7} M 24_{i} * G D P_{i}$ and $\widetilde{W M 24}=\sum_{i=1}^{7} \widetilde{M 24_{\imath}} * G D P_{i} . M 24_{i}$ represents the cumulative impulse response of CEE country $i$ over 24 months to a common shock occurring in the euro area and $G D P_{i}$ is the GDP share. $\widetilde{W M 2} 4_{\iota}$ is equal to the 24 -month ahead cumulative impulse response of CEE country $i$ to a common shock occurring in the euro area when exports

of the founding member $j$ are set to 0 . The lower $\widetilde{R_{M 24}}$ is, the higher the contribution of country $j$ is in explaining contagion effects of EA shocks. Results are presented in Table 2.

\section{INSERT TABLE 2 HERE}

According to Table 2, the main economies in terms of GDP in the Euro area explain a large part of these macroeconomic interdependencies. Germany, France, Italy and Spain considerably impact the CEECs over the period 2004-2015. Excluding the bilateral trade of Germany from the model induces a decrease in the average of multiplier effects of CEECs to a common shock in the EA by $88 \%$ and $89 \%$ over the pre-2004 and post-2004 periods, respectively. These numbers shrink to $69 \%$ and $71 \%$ (respectively) if we impose the bilateral 
trade of France to be zero. We also find that the Netherlands and Belgium play an important role in propagating output shocks to CEECs before 2004. Excluding bilateral trade of these two countries leads to a decrease of $75 \%$ and $44 \%$ in trade spillover effects for Belgium and $53 \%$ and $40 \%$ in the Netherlands. The smallest economies in the Euro area, such as Luxembourg, Greece, Ireland and Finland have negligible impacts.

To sum up, the Czech Republic, Estonia, Poland, Slovakia, and Slovenia are more and more integrated into the EA since their accession to the European Union in 2004. The responses of Lithuania and Hungary, however, only increase when output shocks come from the largest economies in EA-12. The latter economies of the EA have a high degree of diffusion of output shocks to CEECs, especially after the enlargement of the European Union in 2004.

\section{3) Effects of the Euro on spillovers}

We determine which CEECs are significantly impacted by output shocks in EA-12 members and if adopting the euro matters for trade spillover effects. To show evidence on the average impulse response of CEECs-7 to EA-12, we use the following index:

$$
W 2 M 24_{i}=\sum_{j=1}^{12} M 24_{i j} * G D P_{j}
$$

where $G D P_{j}$ is the GDP share of country $j$ in the EA-12 region, and $M 24_{i j}$ is the multiplier effect of the CEE country $i$ of an output shock in country $j$. Results are reported in Table 3.

INSERT TABLE 3 HERE

INSERT TABLE 4 HERE 
We note that responses of CEECs are different between the two sub-periods: before the accession to the European Union, Lithuania, Poland and Hungary are more significantly impacted by EA shocks whereas the smaller economies respond more significantly during the post-accession period. The main result is that the ranking is totally reversed: Lithuania, Hungary and Poland are the top 3 countries before 2004 while the top 3 group is composed of Slovenia, Slovakia and Estonia after 2004. The cumulative impulse responses of these economies are $0.36 \%, 0.40 \%$ and $0.49 \%$, respectively, during the pre-2004 period compared to $3.27 \%, 2.98 \%$ and $2.37 \%$ during the subsequent period. Those three countries adopted the Euro in 2007 (Slovenia), 2009 (Slovakia) and 2011 (Estonia). These empirical results provide evidence that euro adoption significantly increased the macroeconomic interdependencies of CEECs with the initial members of the EA.

Herwartz and Weber (2013) point out that trade between Eurozone countries increased compared to European countries outside the EA. This rise in trade intensity results in stronger trade spillovers. Jiménez-Rodríguez et al. (2010) also highlight that Slovakia and Slovenia react m ore strongly to foreign industrial production shocks than other economies. Estonia exhibits a decrease in trade integration with the EA but an increase in the multiplier effect, as indicated in Table 2. Our results also show that whereas Lithuania reacts strongly before, this economy integrates slowly into the EA after accession to European Union.

According to Frankel and Rose (1998) and Rose (2000), trade patterns and international business cycle correlations are correlated and Optimum Currency Areas are endogenous. Our results show that CEECs that have adopted the Euro benefit from more spillover effects without increasing bilateral trade with the EA. Our results are in line with those of Gonçalves 
et al. (2009). Using a differences-in-differences approach, they find a positive effect of the Euro adoption on synchronization but a negative effect of trade. In the next, we estimate the effects of trade, of the Euro and other variables on spillovers from the EA to the CEECs. 


\section{Dynamic multipliers and the Euro effect}

In this section, the empirical methodology is divided in two parts. First, we use movingwindow estimations to evaluate changes in interdependencies of CEECs-7 with respect to EA12. Cumulative multipliers M24 (estimated from the equation (7)) are simulated from 1996:012004:02 to 2007:06-2015:02.

$$
M M 24_{i,[t, t+138]}=\sum_{s=1}^{24} \Psi_{s,[t ; t+138]} \text { for } \mathrm{t}=1996: 01 \text { to } 2007: 06
$$

In the second part, we identify drivers of such interdependencies. According to the literature (Imbs, 2004, Inklaar et al., 2008, Dées and Zorell, 2012, among others), different factors are considered: trade, industrial specialization, financial integration, and a Euro adoption dummy. We consider two traditional measures of bilateral trade intensity, the first one is calculated using only bilateral trade data:

$$
T R I 1_{i, t}=\frac{X_{i j, t}+M_{i j, t}}{X_{i, t}+M_{i, t}+X_{j, t}+M_{j, t}}
$$

where $X_{i j, t}$ and $M_{i j, t}$ refer to the bilateral export and import between country $i$ and $j$ during the year $t$ in current dollars. $X_{i t}, M_{i t}, X_{j t}$ and $M_{j t}$ denote the total export and total import of country $i$ and $j$, respectively, in the year $t$. Country $i$ is one of the CEECs-7 countries and $j$ is the EA-12.

The second indicator is defined as:

$$
T R I 2_{i, t}=\frac{X_{i j, t}+M_{i j, t}}{Y_{i, t}+Y_{j, t}}
$$

Following Imbs (2004) and Inklaar et al. (2008), specialization is defined as the absolute difference of the GDP share of an industry in two countries, 


$$
S P E_{i, t}=\sum_{s}\left|V_{i s}-V_{j s}\right|
$$

The corresponding data on 27 sectors of goods and services come from the OECD database.

We compute standard deviation of monthly real interest rate differentials $\left(I F I 1_{i j, t}\right)$ using nominal interest rates and consumer price indices. Monetary conditions are captured through three-month interest rates. We use the OECD data.

$$
I F I_{i, t}=\ln \left(\sigma\left(r_{i, t}-r_{j, t}\right)\right)
$$

We add a dummy variable (Euro) with the value 1 when the CEE country starts to use the Euro. We use quarterly data (2002:02 - $2015: 02)$ and we calculate quarterly average for MM24. Results are shown in the Table 5. From equations 1 to 4 , trade intensity (TRI) is not significant for three estimations. In line with Imbs (2004), industrial specialization has a negative impact on interdependencies and financial integration has a mitigate effect on spillovers effect: negative with fixed effect estimations and not significant with random effect estimations. ${ }^{6}$ The Euro dummy variable has always a significant and positive effect.

\section{INSERT TABLE 5 HERE}

In order to investigate this Euro effect, we replicate estimations including an interaction term: trade intensity for CEECs using the Euro (TRI1*Euro and TRI2*Euro). According to the results shown in the Table 5 (equations 5 to 8), trade intensity magnifies economic spillovers from the Euro area to CEECs only for the countries using the Euro. Otherwise, trade dampens spillovers or at least has no effect on contagion. This opposite effects of trade can be justified by different theoretical arguments. First, between two currency areas, spillovers can be limited according to

\footnotetext{
${ }^{6}$ The Hausman test rejects the null hypothesis (random estimation) at $5 \%$ for all equations.
} 
the adjustment of the real exchange rate. According to the relative purchasing power parity (PPP), an increase in the domestic inflation rate (after a positive domestic demand shock) leads to a real depreciation of the domestic currency. This depreciation reduces imports and so contagion to the foreign countries. Furthermore, currency unions coupled with trade integration could facilitate cross-border transmission of price movements and so convergence in inflation rates. In this case, the monetary policy is identical and less counter-cyclical (Robert et al., 2007). Even with controlling for real exchange rate volatility, monetary unions facilitate transmission of prices shock via the trade channel.

From the supply side, if trade changes take the form of intra-industry trade inside currency unions, common shocks and contagion are more frequent inside currency unions than with the other partners (the "European Commission view", De Grauwe, 1997). According to De Grauwe and Ji (2016), spillovers generated by "animal spirits" are higher inside currency unions than with other partners. A wave of optimism in a country leads to more output and imports in that country and spill over to the foreign country. They show that this contagion of optimism is higher inside the currency area and triggered by trade. 


\section{Conclusion}

Since the enlargement of the European Union in 2004, the degree of integration of the Central and Eastern European Countries (CEECs) has been at the center of many debates. Even if Stanisic (2013) rejects the hypothesis of a common business cycle between CEECs, their fluctuations seem to have become closer and closer to those of the EA (Di Giorgio, 2016). Some CEECs have already adopted the euro while others are still candidates. Thus, it was important to determine if entering the EU and adopting the euro lead to a high degree of interdependency.

Relying on a near-VAR model to capture macroeconomic relationships for seven CEECs and twelve EA countries, our empirical results indicate that $i$ ) CEECs countries are more affected by EA shocks after the enlargement in 2004 than before. This result could explain the path of convergence of CEE national business cycles toward those of the EA observed by Stanisic (2013).

Furthermore, we also find ii) that Germany, France and Italy explain a large part of economic disturbances in the CEECs-7 resulting from the EA-12. Germany, France and Italy explain up to $89 \%, 71 \%$ and $69 \%$, respectively, of direct and indirect diffusion of a shock in the EA. This result is in line with Aguiar-Conraria and Soares (2011) and Belke et al. (2016): they find that France and Germany, the core of the EA, are the most synchronized countries with the rest of Europe.

Finally, iii) after the enlargement in 2004, the degree of economic integration increased more for CEECs that have adopted the euro than the other CEECs. Multiplier effects of CEECs from EA-12 disturbances have been multiplied by 9 and 7.4 after 2004 for Slovakia and Estonia 
(which have adopted the euro in 2009 and 2011 respectively) and only by 1.4 and 1.5 for Lithuania and Hungary, for example. Our results are in line with Frankel and Rose (1998), Rose (2000), Koopman and Azevedo (2008), and Furceri and Karras (2008): the euro contributes positively to business cycle synchronization. To test for this "euro effect", we have simulated moving-window multiplier effects (MM24) and we have explained those coefficients by trade intensity, industrial specialization, financial integration, a euro dummy and an interaction term (trade intensity and euro). Results confirm the negative effect of specialization and financial integration but show positive effects of trade only in the context of the euro adoption. The lack of exchange rate volatility, development of intra-industry trade and contagion of "animal spirit" constitute arguments in favor of positive effects of trade inside a currency area.

For further research, it mays be interesting to consider the role played by the structure of trade (intra- and inter-industry) within and outside the EA in this opposite effect of trade. 


\section{References}

Abeysinghe, T., Forbes, K., (2005). Trade linkages and output-multiplier effects: a structural VAR approach with a focus on Asia. Rev. Int. Econ. 13 (2), 356-375.

Aguiar-Conraria L. and Soares M. J. (2011). 'Business Cycle Synchronization and the Euro : A Wavelet Analysis', Journal of Macroeconomics, vol. 33(3), pages 477489.

Artis M. J., Fidrmuc J., and Scharler J., (2008). 'The transmission of business cycles,' The Economics of Transition, The European Bank for Reconstruction and Development, vol. 16(3), pages 559-582, 07.

Baxter M. and Kouparitsas, M. A. (2003). 'Trade Structure, Industrial Structure, and International Business Cycles', American Economic Review, American Economic Association, vol. 93(2), pages 51-56, May.

Baxter M. and Kouparitsas, M. A. (2005). 'Determinants of business cycle comovement: a robust analysis,' Journal of Monetary Economics, Elsevier, vol. 52(1), pages 113-157, January.

Belke, A., Domnick, C., and Gros D. (2016). 'Business cycle synchronization in the EMU: Core vs. periphery,' Ruhr Economic Papers 659, RWI - Leibniz-Institut für Wirtschaftsforschung, Ruhr-University Bochum, TU Dortmund University, University of Duisburg-Essen.

Boone, L. and Maurel, M., (1999). 'An Optimal Currency Area Perspective of the EU Enlargement to the CEECs,' CEPR Discussion Papers 2119, C.E.P.R. Discussion Papers.

Clark T. E. and van Wincoop, E. (2001). 'Borders and business cycles,' Journal of International Economics, Elsevier, vol. 55(1), pages 59-85, October.

Dées S. and Zorell N. (2012). 'Business Cycle Synchronisation: Disentangling Trade and Financial Linkages,' Open Economies Review, Springer, vol. 23(4), pages 623643, September.

De Grauwe, P. (1997), The Economics of Monetary Integration, 3rd. ed., Oxford University Press, London.

De Grauwe P. and Ji Y., (2016), "Animal Spirits and the International Transmission of Business Cycles," CESifo Working Paper Series 5810, CESifo Group Munich.

Di Giorgio C. (2016). 'Business Cycle Synchronization of CEECs with the Euro Area: A Regime Switching Approach', Journal of Common Market Studies, vol. 54(2), pages 284-300.

Dungey, M., Khan, F. and Raghavan, M., (2018), "International trade and the transmission of shocks: The case of ASEAN-4 and NIE-4 economies," Economic Modelling, Elsevier, vol. 72(C), pages 109-121. 
Fidrmuc, J. and Korhonen, I., (2003). 'Similarity of supply and demand shocks between the euro area and the CEECs,' Economic Systems, Elsevier, vol. 27(3), pages 313-334, September.

Fidrmuc, J. and Korhonen, I (2006). 'Meta-Analysis of the Business Cycle Correlation between the Euro Area and the CEECs', Journal of Comparative Economics, Elsevier, vol. 34(3), pages 518-537, September.

Frankel, J. A. and Rose, A. K., (1998). 'The Endogeneity of the Optimum Currency Area Criteria,' Economic Journal, Royal Economic Society, vol. 108(449), pages 1009-25, July.

Furceri D. and Karras G. (2008). 'Business-Cycle Synchronization in the EMU', Applied Economics, vol. 40(12), pages 1491-1501.

Gonçalves, C. E. S. and Rodrigues, M. and Soares, T., (2009). "Correlation of business cycles in the euro zone," Economics Letters, Elsevier, vol. 102(1), pages 56-58, January.

Gouveia S., and Correia L. (2013). 'Trade Integration and Business Cycle Synchronization in the Euro Area: The Case of Southern European Countries,' Journal of Economic Integration, Center for Economic Integration, Sejong University, vol. 28, pages 85107.

Herwartz, H. and Weber, H., (2013). 'The role of cross-sectional heterogeneity for magnitude and timing of the euro's trade effect,' Journal of International Money and Finance, Elsevier, vol. 37(C), pages 48-74.

Imbs J. (2004). 'Trade, Finance, Specialization and Synchronization,' The Review of Economics and Statistics, MIT Press, vol. 86(3), pages 723-734, August.

Inklaar, Robert, Jong-A-Pin, Richard, de Haan, Jakob, 2008. "Trade and business cycle synchronization in OECD countries--A re-examination," European Economic Review, Elsevier, vol. 52(4), pages 646-666, May.

IMF (2012), 2012 Spillover Report, Washington.

Jimenez-Rodríguez R., Morales-Zumaquero A. and Egert B. (2010). 'The effect of Foreign Shocks in Central and Eastern Europe', Journal of Policy Modeling, 32 461-477

Jimenez-Rodríguez R., Morales-Zumaquero A. and Egert B. (2013). 'Business Cycle Synchronization between Euro Area and Central and Eastern European Countries", Review of Development Economics, 17(2) 379-395

Kenen P., (1969). 'The Theory of Optimum Currency Areas: An Eclectic View' in Mundell and Swoboda (eds.) Monetary Problems in the International Economy, University of Chicago Press, Chicago. 
Keppel C. and Prettner K. (2015). 'How interdependent are eastern European economies and the Euro area?,' The Quarterly Review of Economics and Finance, Elsevier, vol. 58(C), pages 18-31.

Koopman S. J. and Azevedo J. V. (2008). 'Measuring Synchronization and Convergence of Business Cycles for the Euro Area, UK and US', Oxford Bulletin of Economics and Statistics, vol. 70(1), pages 23-51.

Korhonen I., (2003). 'Some empirical tests on the integration of economic activity between the euro area and the accession countries,' The Economics of Transition, The European Bank for Reconstruction and Development, vol. 11(1), pages 177-196, March.

Krugman P. R. (1993). 'Lessons of Massachusetts for EMU', in Adjustment and growth in the European Monetary Union, Cambridge University Press, F. Torres, F. Giavazzi (eds), p.241-69.

McKinnon, R., (1963). 'Optimum Currency Area', American Economic Review, September, pp. 717-725.

Mundell, R. A. (1961). 'A theory of optimum currency area', American Economic Review, 51, 657-665.

Robert, A., Baldwin, R. and Taglioni, D., (2007), "The impact of monetary union on trade prices," Journal of Financial Transformation, Capco Institute, vol. 19, pages 35-48.

Rose A. K. (2000). 'One money, one market: the effect of common currencies on trade,' Economic Policy, CEPR; CES; MSH, vol. 15(30), pages 7-46, 04.

Siedschlag I. (2010),. 'Patterns and determinants of business cycle synchronization in the enlarged European Economic and Monetary Union,' Eastern Journal of European Studies, Centre for European Studies, AlexandruIoan Cuza University, vol. 1, pages 21-44, June.

Stanisic N. (2013). 'Convergence between the business cycles of Central and Eastern European countries and the Euro area', Baltic Journal of Economics, Baltic International Centre for Economic Policy Studies, vol. 13(1), pages 63-74, July.

Wang J. and Zivot E. (2000),. 'A Bayesian Time Series Model of Multiple Structural Changes in Level, Trend and Variance', Journal of Business and Economics, 18 : 374386. 
Table 1: Multiplier effects and Trade intensity after/before 2004

\begin{tabular}{|c|c|c|c|c|c|c|c|c|c|c|c|c|c|c|c|}
\hline & \multicolumn{2}{|c|}{ CZE } & \multicolumn{2}{|c|}{ EST } & \multicolumn{2}{|c|}{ HUN } & \multicolumn{2}{|c|}{ POL } & \multicolumn{2}{|c|}{ SVK } & \multicolumn{2}{|c|}{ SVN } & \multicolumn{2}{|c|}{ LTU } & \multirow{2}{*}{$\begin{array}{l}\text { Correlations } \\
\left(\mathrm{R}_{\mathrm{M} 24} ; \mathrm{R}_{\mathrm{TI}}\right)\end{array}$} \\
\hline & $\mathrm{R}_{\mathrm{M} 24}$ & $\mathrm{R}_{\mathrm{TI}}$ & $\mathrm{R}_{\mathrm{M} 24}$ & $\mathrm{R}_{\mathrm{TI}}$ & $\mathrm{R}_{\mathrm{M} 24}$ & $\mathrm{R}_{\mathrm{TI}}$ & $\mathrm{R}_{\mathrm{M} 24}$ & $\mathrm{R}_{\mathrm{TI}}$ & $\mathrm{R}_{\mathrm{M} 24}$ & $\mathrm{R}_{\mathrm{TI}}$ & $\mathrm{R}_{\mathrm{M} 24}$ & $\mathrm{R}_{\mathrm{TI}}$ & $\mathrm{R}_{\mathrm{M} 24}$ & $\mathrm{R}_{\mathrm{TI}}$ & \\
\hline AUT & 2.53 & 0.98 & 4.08 & 0.98 & 0.71 & 0.82 & 2.26 & 1.39 & 4.57 & 1.12 & 2.58 & 1.27 & 0.79 & 1.11 & 0.16 \\
\hline BEL & 2.86 & 1.22 & 4.24 & 1.07 & 0.87 & 0.9 & 2.46 & 1.18 & 5.21 & 1.19 & 2.85 & 1.32 & 0.78 & 1.57 & -0.18 \\
\hline FIN & 7.94 & 1.07 & 10.38 & 0.64 & 2.39 & 0.62 & 6.84 & 1.00 & 14.44 & 1.21 & 7.80 & 1.02 & 2.77 & 0.98 & 0.45 \\
\hline FRA & 3.52 & 1.36 & 5.12 & 1.07 & 1.09 & 1.14 & 3.05 & 1.29 & 6.41 & 2.15 & 3.40 & 0.88 & 0.94 & 1.05 & 0.64 \\
\hline DEU & 6.29 & 1.10 & 9.57 & 0.92 & 1.97 & 1.05 & 5.51 & 1.24 & 11.54 & 1.32 & 6.19 & 1.00 & 1.78 & 0.9 & 0.46 \\
\hline IRL & 2.41 & 1.05 & 3.49 & 0.60 & 0.74 & 0.72 & 2.17 & 1.52 & 4.59 & 1.53 & 2.47 & 1.19 & 0.66 & 0.78 & 0.47 \\
\hline ITA & 3.52 & 1.19 & 5.2 & 0.81 & 1.10 & 0.90 & 3.08 & 1.13 & 6.38 & 1.10 & 3.39 & 1.05 & 0.97 & 1.14 & -0.10 \\
\hline LUX & 2.09 & 1.22 & 3.04 & 1.84 & 0.66 & 1.26 & 1.85 & 1.63 & 3.91 & 1.44 & 2.15 & 1.37 & 0.59 & 1.02 & 0.62 \\
\hline NLD & 4.78 & 1.39 & 7.14 & 0.78 & 1.46 & 1.20 & 4.12 & 1.31 & 8.89 & 1.59 & 4.77 & 1.31 & 1.31 & 1.45 & -0.06 \\
\hline PRT & 2.64 & 1.89 & 3.82 & 0.69 & 0.81 & 0.99 & 2.26 & 1.23 & 4.82 & 2.56 & 2.63 & 2.11 & 0.72 & 1.34 & 0.46 \\
\hline SPA & 4.47 & 1.64 & 6.52 & 1.24 & 1.41 & 1.46 & 3.93 & 1.55 & 8.32 & 1.90 & 4.41 & 1.43 & 1.22 & 1.54 & 0.33 \\
\hline GRC & 2.48 & 1.03 & 3.59 & 1.13 & 0.79 & 1.38 & 2.18 & 1.58 & 4.61 & 2.13 & 2.5 & 1.54 & 0.68 & 0.54 & 0.65 \\
\hline EA-12 & 3.41 & 1.15 & 5.14 & 0.78 & 1.05 & 1.02 & 2.97 & 1.25 & 6.23 & 1.36 & 3.33 & 1.07 & 0.95 & 1.07 & 0.18 \\
\hline
\end{tabular}

Notes: (i) AUT-Austria, BEL-Belgium, FIN-Finland, FRA-France, DEU-Germany, GRC-Greece, IRL-Ireland, ITA-Italy, LUX-Luxembourg, NLDNetherlands, PRT-Portugal, SPA-Spain, EST-Estonia, HUN-Hungary, LTU-Lithuania, POL-Poland, CZE- Czech Republic, SVK-Slovakia, SVN, Slovenia.

(ii) $\mathrm{R}_{\mathrm{M} 24}$ represents the ratio of IRFs after/before 2004 enlargement for the country in column to a shock of the country in row.

(iii) $\mathrm{R}_{\mathrm{TI}}$ represents variation (after/before 2004 enlargement) of trade openness between the country in column and the country in row. (iv) in italics, $\mathrm{R}_{\mathrm{TI}}$ numbers lower than 1. 
Table 2: Degree of shock diffusion and Ranking

\begin{tabular}{ccccc}
\hline & \multicolumn{2}{c}{$\widetilde{R_{M 24}}$} & \multicolumn{2}{c}{ Rank } \\
& Pre-2004 & Post-2004 & Pre-2004 & Post-2004 \\
\hline GER & 0.12 & 0.11 & 1 & 1 \\
FRA & 0.31 & 0.29 & 3 & 2 \\
ITA & 0.57 & 0.31 & 6 & 3 \\
SPA & 0.52 & 0.47 & 5 & 4 \\
BEL & 0.25 & 0.56 & 2 & 5 \\
NLD & 0.47 & 0.60 & 4 & 6 \\
AUT & 0.57 & 0.67 & 7 & 7 \\
PRT & 0.88 & 0.81 & 10 & 8 \\
FIN & 0.84 & 0.83 & 9 & 9 \\
GRC & 0.89 & 0.93 & 11 & 10 \\
LUX & 1.00 & 0.94 & 12 & 11 \\
IRL & 0.64 & 0.98 & 8 & 12
\end{tabular}

Note: AUT: Austria, BEL: Belgium, FIN: Finland, FRA: France, GER: Germany, GRC: Greece, IRL: Ireland, ITA: Italia, LUX: Luxembourg, NLD: the Netherlands, PRT: Portugal, SPA: Spain

Table 3: Effect of adopting the euro

\begin{tabular}{llcccc}
\hline Country & Pre-2004 & Post-2004 & Pre-2004 & Post-2004 & $\begin{array}{c}\text { EA } \\
\text { member } \\
\text { since }\end{array}$ \\
\hline \hline SVK & 0.36 & 3.27 & 7 & 1 & 2009 \\
EST & 0.40 & 2.98 & 6 & 2 & 2011 \\
SVN & 0.49 & 2.37 & 4 & 3 & 2007 \\
CZE & 0.43 & 2.16 & 5 & 4 & \\
POL & 0.49 & 2.13 & 3 & 5 & \\
HUN & 1.02 & 1.58 & 2 & 6 & \\
LTU & 1.05 & 1.45 & 1 & 7 & 2015 \\
\hline
\end{tabular}

Note: CZE: Republic Czech, EST: Estonia, HUN: Hungary, LTU:

Lithuania, POL: Poland, SVK: Slovakia, SVN: Slovenia. 
Table 4: Mean of Ratios of Multiplier effects and Trade intensity (CEECs' responses for a shock in EA-12)

\begin{tabular}{lcc}
\hline & $\mathrm{R}_{\mathrm{M} 24}$ & $\mathrm{R}_{\mathrm{TI}}$ \\
\hline All countries & 3.3 & 1.10 \\
EST+SVK+SVN & 4.9 & 1.07 \\
CZE+HUN+POL+LTU & 2.1 & 1.12 \\
\hline
\end{tabular}


Table 5: Panel Estimations for moving-window coefficients MM24 (2004:02-2015:02)

\begin{tabular}{|c|c|c|c|c|c|c|c|c|}
\hline MM24 & $\begin{array}{l}\text { FE } \\
\text { (1) }\end{array}$ & $\begin{array}{l}\mathrm{FE} \\
\text { (2) }\end{array}$ & $\begin{array}{l}\text { RE } \\
\text { (3) }\end{array}$ & $\begin{array}{l}\text { RE } \\
\text { (4) }\end{array}$ & $\begin{array}{l}\text { FE } \\
\text { (5) }\end{array}$ & $\begin{array}{l}\text { FE } \\
\text { (6) }\end{array}$ & $\begin{array}{l}\text { RE } \\
\text { (7) }\end{array}$ & $\begin{array}{l}\text { RE } \\
\text { (8) }\end{array}$ \\
\hline TRI1 & $\begin{array}{l}-0.233^{* *} \\
(0.114)\end{array}$ & & $\begin{array}{l}-0.027 \\
(0.087)\end{array}$ & & $\begin{array}{c}-0.428^{* * *} \\
(0.097)\end{array}$ & & $\begin{array}{l}-0.178^{* *} \\
(0.073)\end{array}$ & \\
\hline TRI2 & & $\begin{array}{l}-0.184 \\
(0.473)\end{array}$ & & $\begin{array}{c}0.500 \\
(0.305)\end{array}$ & & $\begin{array}{l}-0.485 \\
(0.429)\end{array}$ & & $\begin{array}{c}0.103 \\
(0.271)\end{array}$ \\
\hline SPE & $\begin{array}{l}-0.021^{* * *} \\
(0.003)\end{array}$ & $\begin{array}{c}-0.020^{* * *} \\
(0.003)\end{array}$ & $\begin{array}{c}-0.007^{* * *} \\
(0.003)\end{array}$ & $\begin{array}{c}-0.007^{* * *} \\
(0.002)\end{array}$ & $\begin{array}{c}-0.015^{* * *} \\
(0.003)\end{array}$ & $\begin{array}{c}-0.016^{* * *} \\
(0.003)\end{array}$ & $\begin{array}{l}-0.002 \\
(0.002)\end{array}$ & $\begin{array}{l}-0.004^{*} \\
(0.002)\end{array}$ \\
\hline IFI & $\begin{array}{c}-0.055^{* * *} \\
(0.017)\end{array}$ & $\begin{array}{l}-0.050^{* * *} \\
(0.018)\end{array}$ & $\begin{array}{l}-0.016 \\
(0.014)\end{array}$ & $\begin{array}{l}-0.013 \\
(0.014)\end{array}$ & $\begin{array}{l}-0.034^{* *} \\
(0.015)\end{array}$ & $\begin{array}{l}-0.036^{* *} \\
(0.016)\end{array}$ & $\begin{array}{l}-0.005 \\
(0.013)\end{array}$ & $\begin{array}{l}-0.006 \\
(0.013)\end{array}$ \\
\hline Euro & $\begin{array}{l}0.001^{* * *} \\
(0.0003)\end{array}$ & $\begin{array}{l}0.002^{* * *} \\
(0.0003)\end{array}$ & $\begin{array}{l}0.003^{* * *} \\
(0.0002)\end{array}$ & $\begin{array}{l}0.002^{* * *} \\
(0.0002)\end{array}$ & $\begin{array}{l}-0.002^{* * *} \\
(0.0004)\end{array}$ & $\begin{array}{l}-0.001^{* * *} \\
(0.0004)\end{array}$ & $\begin{array}{c}-0.001 \\
(0.0004)\end{array}$ & $\begin{array}{r}-0.00004 \\
(0.0004)\end{array}$ \\
\hline TRI1*Euro & & & & & $\begin{array}{l}0.801^{* * *} \\
(0.076)\end{array}$ & & $\begin{array}{l}0.799^{* * *} \\
(0.082)\end{array}$ & \\
\hline TRI2*Euro & & & & & & $\begin{array}{l}3.538^{* * *} \\
(0.459)\end{array}$ & & $\begin{array}{l}3.740^{* * *} \\
(0.478)\end{array}$ \\
\hline Constant & & & $\begin{array}{l}0.005^{* * *} \\
(0.001)\end{array}$ & $\begin{array}{l}0.005^{* * *} \\
(0.001)\end{array}$ & & & $\begin{array}{l}0.006^{* * *} \\
(0.001)\end{array}$ & $\begin{array}{l}0.005^{* * *} \\
(0.001)\end{array}$ \\
\hline Obs. & 315 & 315 & 315 & 315 & 315 & 315 & 315 & 315 \\
\hline $\mathrm{R}^{2}$ & 0.350 & 0.340 & 0.339 & 0.345 & 0.514 & 0.456 & 0.492 & 0.452 \\
\hline Adjusted $\mathrm{R}^{2}$ & 0.215 & 0.203 & 0.330 & 0.336 & 0.413 & 0.343 & 0.486 & 0.445 \\
\hline F Statistic & $34.972^{* * *}$ & $33.437^{* * *}$ & $39.738^{* * *}$ & $40.780^{* * *}$ & $68.686^{* * *}$ & $54.546^{* * *}$ & $75.097^{* * *}$ & $63.815^{* *}$ \\
\hline
\end{tabular}

Note: $\quad$ Standard errors under parenthesis. ${ }^{*} \mathrm{p}<0.1 ;{ }^{* *} \mathrm{p}<0.05 ;{ }^{* * *} \mathrm{p}<0.01$.

FE for fixed effects estimation and RE for random estimation.

All equations include individual and time effects. 


\section{Online Appendix}

\section{Table A.1 Model Specification Tests}

\begin{tabular}{|c|c|c|c|c|c|c|c|c|c|c|c|c|}
\hline & \multicolumn{3}{|c|}{ Jan 1996-Sept 2015} & \multirow[b]{2}{*}{ AIC } & \multirow[b]{2}{*}{ LAGs } & \multicolumn{2}{|c|}{ Pre-accession } & \multirow{2}{*}{$\begin{array}{r}\text { model } \\
\text { AIC }\end{array}$} & \multicolumn{4}{|c|}{ Post-accession model } \\
\hline & LAGs & LB & JB & & & LB & $\mathbf{J B}$ & & LAGs & LB & $\mathbf{J B}$ & AIC \\
\hline $\mathrm{CZE}$ & $(2,2,7)$ & 0.36 & 0.03 & -463.10 & $(1,2,2)$ & 0.46 & 0.18 & -238.36 & $(3,1,11)$ & 0.19 & 0.82 & -363.61 \\
\hline EST & $(2,2,7)$ & 0.38 & 0.03 & -396.00 & $(1,1,1)$ & 0.11 & 0.90 & -221.80 & $(8,3,5)$ & 0.93 & 0.02 & -299.65 \\
\hline HUN & $(2,3,8)$ & 0.94 & 0.00 & -502.82 & $(2,3,1)$ & 0.06 & 0.41 & -271.76 & $(2,1,7)$ & 0.43 & 0.00 & -372.33 \\
\hline POL & $(1,1,1)$ & 0.08 & 0.00 & -571.99 & $(2,3,3)$ & 0.55 & 0.28 & -277.70 & $(2,1,7)$ & 0.42 & 0.55 & -468.57 \\
\hline SVK & $(1,1,1)$ & 0.71 & 0.00 & -350.76 & $(3,1,5)$ & 0.27 & 0.22 & -256.14 & $(2,1,7)$ & 0.17 & 0.02 & -258.18 \\
\hline SVN & $(8,5,11)$ & 0.05 & 0.00 & -542.21 & $(3,3,1)$ & 0.42 & 0.00 & -306.86 & $(2,2,5)$ & 0.53 & 0.00 & -397.06 \\
\hline LTU & $(7,1,1)$ & 0.99 & 0.00 & -87.65 & $(3,4,1)$ & 0.29 & 0.87 & -60.52 & $(10,6,1)$ & 0.74 & 0.00 & -164.00 \\
\hline AUT & $(5,5,11)$ & 0.50 & 0.00 & -669.48 & $(12,3,3)$ & 0.60 & 0.01 & -320.20 & $(2,2,9)$ & 0.74 & 0.96 & -472.35 \\
\hline BEL & $(4,3,4)$ & 0.87 & 0.00 & -576.11 & $(2,3,7)$ & 0.71 & 0.00 & -340.90 & $(3,4,7)$ & 0.39 & 0.93 & -399.44 \\
\hline FIN & $(2,3,8)$ & 0.11 & 0.00 & -612.06 & $(6,6,3)$ & 0.42 & 0.48 & -350.13 & $(2,1,7)$ & 0.66 & 0.00 & -399.34 \\
\hline FRA & $(3,3,12)$ & 0.59 & 0.02 & -826.19 & $(6,2,1)$ & 0.53 & 0.00 & -431.70 & $(2,2,9)$ & 0.39 & 0.23 & -537.94 \\
\hline GER & $(2,3,8)$ & 0.74 & 0.77 & -751.54 & $(4,1,5)$ & 0.05 & 0.62 & -416.51 & $(1,3,1)$ & 0.32 & 0.12 & -475.01 \\
\hline IRL & $(3,1,10)$ & 0.14 & 0.00 & -105.91 & $(3,2,10)$ & 0.55 & 0.44 & -149.49 & $(3,5,7)$ & 0.21 & 0.00 & -109.49 \\
\hline ITA & $(2,3,8)$ & 0.44 & 0.39 & -822.26 & $(1,3,2)$ & 0.83 & 0.07 & -463.94 & $(3,3,2)$ & 0.20 & 0.44 & -531.01 \\
\hline LUX & $(3,2,11)$ & 0.25 & 0.00 & -304.83 & $(6,2,5)$ & 0.60 & 0.00 & -187.54 & $(2,2,9)$ & 0.56 & 0.00 & -245.11 \\
\hline NLD & $(3,3,12)$ & 0.16 & 0.16 & -541.36 & $(3,4,12)$ & 0.74 & 0.46 & -317.86 & $(1,1,1)$ & 0.13 & 0.81 & -368.08 \\
\hline PRT & $(3,3,12)$ & 0.78 & 0.98 & -529.89 & $(2,2,5)$ & 0.95 & 0.06 & -308.49 & $(2,1,3)$ & 0.19 & 0.76 & -398.43 \\
\hline GRC & $(10,4,1)$ & 0.06 & 0.00 & -477.86 & $(2,2,5)$ & 0.62 & 0.00 & -285.99 & $(4,0,1)$ & 0.11 & 0.39 & -358.25 \\
\hline SPA & $(6,3,8)$ & 0.11 & 0.00 & 720.66 & $(2,2,5)$ & 0.55 & 0.01 & -410.04 & $(1,1,2)$ & 0.08 & 0.38 & -524.90 \\
\hline
\end{tabular}

Notes: LB, JB denote p-value of Ljung-Box test and Jarque-Berra test, respectively. LAGs represent lags of national output (y), international output $\left(\mathrm{y}^{\mathrm{e}}\right)$ and rest of the word's output. AIC refers to Akaike Information Criterion. Country code: AUT: Austria, BEL: Belgium, FIN: Finland, FRA: France, GER: Germany, GRC : Greece, IRL: Ireland, ITA : Italia, LUX: Luxembourg, NLD: Netherlands, PRT: Portugal, SPA: Spain, EST: Estonia, HUN: Hungary, LTU: Lithuania, POL: Poland, CZE: Republic Czech, SVK: Slovakia, SVN: Slovenia. 
Table A.2 Chow tests (P-values) for breaks in near-VAR models

\begin{tabular}{|c|c|c|c|c|c|c|c|c|c|c|c|}
\hline \multirow[b]{2}{*}{ Country } & \multicolumn{2}{|c|}{ 1996-2004 } & \multicolumn{3}{|c|}{ 1996-2015 } & \multicolumn{6}{|c|}{$2004-2015$} \\
\hline & $\begin{array}{l}\text { Dec- } \\
98\end{array}$ & $\begin{array}{l}\text { Dec- } \\
00\end{array}$ & $\begin{array}{l}\text { May- } \\
04\end{array}$ & $\begin{array}{l}\text { Jan- } \\
11\end{array}$ & $\begin{array}{l}\text { Jan- } \\
09\end{array}$ & $\begin{array}{l}\text { Jan- } \\
07\end{array}$ & $\begin{array}{l}\text { Sep- } \\
08\end{array}$ & $\begin{array}{l}\text { Oct- } \\
08\end{array}$ & $\begin{array}{l}\text { Nov- } \\
08\end{array}$ & $\begin{array}{l}\text { Dec- } \\
08\end{array}$ & $\begin{array}{l}\text { Sep- } \\
12\end{array}$ \\
\hline CZE & & & 0.67 & & & & 0.78 & 0.78 & 0.82 & 0.82 & 0.63 \\
\hline EST & & & 0.03 & 0.99 & & & 0.72 & 0.71 & 0.59 & 0.94 & 0.99 \\
\hline HUN & & & 0.44 & & & & 0.97 & 0.97 & 0.97 & 0.95 & 0.31 \\
\hline POL & & & 0.03 & & & & 0.1 & 0.1 & 0.34 & 0.16 & 0.50 \\
\hline SVK & & & 0.90 & & 0.46 & & 0.72 & 0.73 & 0.67 & 0.66 & 0.56 \\
\hline SVN & & & 0.41 & & & 0.87 & 0.94 & 0.94 & 0.78 & 0.73 & 0.65 \\
\hline LTU & & & 0.92 & & & & 0.93 & 0.93 & 0.9 & 0.84 & 0.97 \\
\hline AUT & 1.00 & & 0.50 & & & & 0.98 & 0.98 & 0.99 & 0.89 & 0.90 \\
\hline BEL & 0.80 & & 0.06 & & & & 0.85 & 0.83 & 0.83 & 0.83 & 0.71 \\
\hline FIN & 0.90 & & 0.40 & & & & 0.36 & 0.37 & 0.35 & 0.35 & 0.98 \\
\hline FRA & 0.34 & & 0.83 & & & & 0.26 & 0.26 & 0.27 & 0.44 & 0.74 \\
\hline DEU & 0.68 & & 0.29 & & & & 0.44 & 0.45 & 0.39 & 0.57 & 0.99 \\
\hline IRL & 1.00 & & 0.27 & & & & 0.90 & 0.89 & 0.91 & 0.85 & 0.09 \\
\hline ITA & 0.64 & & 0.14 & & & & 0.08 & 0.05 & 0.05 & 0.05 & 0.65 \\
\hline LUX & 0.70 & & 0.23 & & & & 0.91 & 0.91 & 0.87 & 0.80 & 0.99 \\
\hline NLD & 1.00 & & 0.90 & & & & 0.97 & 0.99 & 0.96 & 0.96 & 0.96 \\
\hline PRT & 0.64 & & 0.48 & & & & 0.27 & 0.29 & 0.36 & 0.42 & 0.91 \\
\hline GRC & & 0.10 & 0.89 & & & & 0.63 & 0.66 & 0.81 & 0.74 & 0.86 \\
\hline SPA & 0.17 & & 0.85 & & & & 0.83 & 0.70 & 0.44 & 0.22 & 0.88 \\
\hline
\end{tabular}

Notes: (i) AUT-Austria, BEL-Belgium, FIN-Finland, FRA-France, DEU-Germany, GRC-Greece, IRLIreland, ITA-Italy, LUX-Luxembourg, NLD-Netherlands, PRT-Portugal, ESP-Spain, EST-Estonia, HUNHungary, LTU-Lithuania, POL-Poland, CZE- Czech Republic, SVK-Slovakia, SVN, Slovenia.

(ii) In bold, significant breaks at 5\%. 
Table A.3 Residual analysis

\begin{tabular}{|c|c|c|c|c|c|c|c|c|c|c|}
\hline & CZE & EST & HUN & POL & SVK & SVN & LTU & AUT & & BEL \\
\hline CZE & & -0.01 & 0.21 & 0.38 & -0.05 & 0.15 & 0.06 & 0.06 & & -0.19 \\
\hline EST & 0.01 & & -0.03 & -0.02 & 0.05 & 0.18 & 0.29 & 0.00 & & -0.20 \\
\hline HUN & 0.03 & 0.05 & & 0.19 & 0.11 & 0.12 & 0.18 & -0.04 & & -0.14 \\
\hline POL & -0.01 & 0.07 & 0.27 & & -0.06 & 0.21 & 0.01 & -0.09 & & -0.02 \\
\hline SVK & 0.03 & -0.09 & -0.17 & 0.13 & & 0.26 & 0.08 & -0.17 & & -0.06 \\
\hline SVN & -0.08 & -0.19 & 0.06 & -0.06 & 0.05 & & 0.01 & -0.13 & & -0.20 \\
\hline LTU & 0.12 & -0.12 & 0.01 & -0.23 & -0.05 & 0.04 & & -0.09 & & 0.02 \\
\hline AUT & -0.02 & 0.01 & 0.09 & 0.16 & 0.06 & -0.06 & -0.01 & & & 0.11 \\
\hline BEL & -0.19 & 0.09 & 0.03 & 0.16 & -0.04 & -0.24 & -0.02 & -0.01 & & \\
\hline FIN & 0.11 & -0.37 & -0.04 & 0.06 & 0.27 & 0.10 & -0.06 & -0.21 & & -0.08 \\
\hline FRA & 0.29 & 0.13 & -0.09 & -0.13 & -0.01 & 0.09 & 0.23 & 0.03 & & -0.11 \\
\hline DEU & -0.32 & 0.12 & -0.05 & -0.21 & -0.35 & 0.15 & -0.06 & -0.12 & & -0.11 \\
\hline IRL & 0.02 & -0.07 & 0.11 & -0.04 & -0.09 & 0.02 & 0.08 & -0.13 & & -0.18 \\
\hline ITA & -0.09 & 0.15 & -0.01 & 0.22 & -0.04 & -0.13 & -0.08 & -0.05 & & 0.06 \\
\hline LUX & -0.04 & -0.01 & 0.01 & -0.13 & 0.08 & 0.25 & 0.00 & -0.14 & & -0.25 \\
\hline NLD & 0.06 & 0.06 & 0.03 & -0.13 & 0.08 & 0.08 & 0.15 & -0.02 & & -0.10 \\
\hline PRT & -0.12 & 0.08 & -0.01 & 0.10 & 0.13 & 0.08 & -0.10 & -0.06 & & 0.04 \\
\hline GRC & 0.13 & -0.08 & -0.04 & 0.08 & 0.16 & -0.08 & -0.11 & 0.08 & & -0.17 \\
\hline ESP & -0.03 & -0.13 & 0.04 & -0.05 & 0.12 & 0.04 & 0.11 & 0.01 & & 0.01 \\
\hline & FRA & DEU & IRL & ITA & LUX & NLD & PRT & GRC & ESP & \\
\hline $\mathrm{CZE}$ & -0.13 & -0.10 & 0.07 & 0.18 & 0.21 & 0.18 & 0.17 & -0.11 & 0.01 & \\
\hline EST & 0.22 & -0.21 & -0.13 & -0.05 & 0.04 & 0.17 & 0.11 & 0.22 & 0.05 & \\
\hline HUN & -0.14 & 0.10 & -0.12 & 0.10 & -0.17 & -0.19 & -0.04 & 0.07 & 0.07 & \\
\hline POL & -0.18 & -0.01 & -0.13 & 0.13 & 0.24 & 0.04 & 0.00 & -0.05 & -0.13 & \\
\hline SVK & -0.11 & 0.32 & -0.29 & -0.14 & 0.04 & -0.23 & -0.01 & -0.20 & 0.18 & \\
\hline SVN & 0.09 & 0.15 & -0.04 & 0.01 & 0.08 & 0.17 & -0.08 & -0.08 & 0.08 & \\
\hline LTU & 0.13 & -0.18 & -0.04 & -0.08 & -0.03 & 0.15 & -0.03 & 0.00 & -0.07 & \\
\hline AUT & 0.20 & -0.47 & -0.02 & 0.08 & 0.14 & 0.26 & 0.08 & -0.01 & -0.30 & \\
\hline BEL & -0.34 & -0.15 & -0.09 & -0.01 & -0.04 & -0.19 & -0.05 & -0.13 & -0.07 & \\
\hline FIN & -0.04 & 0.08 & 0.05 & -0.13 & 0.01 & 0.16 & 0.24 & -0.12 & -0.03 & \\
\hline FRA & & -0.33 & 0.01 & -0.13 & 0.03 & 0.39 & 0.00 & -0.14 & -0.21 & \\
\hline DEU & -0.24 & & -0.01 & -0.26 & -0.23 & -0.27 & -0.13 & -0.23 & 0.20 & \\
\hline IRL & -0.01 & 0.01 & & -0.04 & 0.11 & 0.12 & -0.12 & 0.10 & -0.03 & \\
\hline ITA & -0.19 & -0.18 & -0.10 & & 0.12 & 0.03 & -0.07 & 0.01 & -0.31 & \\
\hline LUX & 0.07 & 0.04 & 0.06 & -0.05 & & 0.14 & -0.03 & -0.12 & -0.21 & \\
\hline NLD & $\mathbf{0 . 3 7}$ & -0.09 & 0.06 & -0.06 & 0.10 & & 0.02 & -0.12 & -0.24 & \\
\hline PRT & -0.21 & 0.11 & 0.12 & 0.07 & -0.13 & -0.23 & & -0.24 & -0.04 & \\
\hline GRC & -0.04 & -0.29 & 0.08 & -0.02 & 0.20 & 0.02 & -0.25 & & 0.15 & \\
\hline ESP & 0.10 & -0.08 & 0.20 & -0.22 & 0.14 & 0.13 & -0.12 & 0.15 & & \\
\hline
\end{tabular}

Notes: Lower triangular matrix consists of correlations of residuals from the post-accession model. Upper triangular matrix consists of correlations of residuals from the pre-accession model. Country code: AUT: Austria, BEL: Belgium, FIN: Finland, FRA: France, DEU: Germany, GRC: Greece, IRL: Ireland, ITA: Italia, LUX: Luxembourg, NLD: Netherlands, PRT: Portugal, ESP: Spain, EST: Estonia, HUN: Hungary, LTU: Lithuania, POL: Poland, CZE: Republic Czech, SVK: Slovakia, SVN: Slovenia. In bold, correlations larger than 0.30. 
Table A.4 Multiplier effects before and after the accession (\%)

\begin{tabular}{|c|c|c|c|c|c|c|c|c|c|c|c|c|c|c|}
\hline & \multicolumn{2}{|c|}{ CZE } & \multicolumn{2}{|c|}{ EST } & \multicolumn{2}{|c|}{ HUN } & \multicolumn{2}{|c|}{ POL } & \multicolumn{2}{|c|}{ SVK } & \multicolumn{2}{|c|}{ SVN } & \multicolumn{2}{|c|}{ LTU } \\
\hline & $\begin{array}{l}\text { Pre- } \\
2004 \\
\end{array}$ & $\begin{array}{l}\text { Post- } \\
2004 \\
\end{array}$ & $\begin{array}{c}\text { Pre- } \\
2004 \\
\end{array}$ & $\begin{array}{l}\text { Post- } \\
2004 \\
\end{array}$ & $\begin{array}{l}\text { Pre- } \\
2004 \\
\end{array}$ & $\begin{array}{l}\text { Post- } \\
2004 \\
\end{array}$ & $\begin{array}{l}\text { Pre- } \\
2004 \\
\end{array}$ & $\begin{array}{l}\text { Post- } \\
2004 \\
\end{array}$ & $\begin{array}{l}\text { Pre- } \\
2004 \\
\end{array}$ & $\begin{array}{l}\text { Post- } \\
2004 \\
\end{array}$ & $\begin{array}{c}\text { Pre- } \\
2004 \\
\end{array}$ & $\begin{array}{l}\text { Post- } \\
2004 \\
\end{array}$ & $\begin{array}{l}\text { Pre- } \\
2004 \\
\end{array}$ & $\begin{array}{l}\text { Post- } \\
2004 \\
\end{array}$ \\
\hline AUT & 0.22 & 0.55 & 0.17 & 0.70 & 0.57 & 0.41 & 0.23 & 0.52 & 0.19 & 0.85 & 0.25 & 0.65 & 0.43 & 0.34 \\
\hline BEL & 0.32 & 0.92 & 0.31 & 1.33 & 0.76 & 0.67 & 0.37 & 0.91 & 0.27 & 1.39 & 0.35 & 1.00 & 0.82 & 0.64 \\
\hline FIN & 0.03 & 0.27 & 0.14 & 1.45 & 0.08 & 0.20 & 0.04 & 0.28 & 0.03 & 0.42 & 0.04 & 0.29 & 0.11 & 0.30 \\
\hline FRA & 0.39 & 1.38 & 0.38 & 1.94 & 0.93 & 1.01 & 0.45 & 1.38 & 0.33 & 2.12 & 0.46 & 1.56 & 1.01 & 0.95 \\
\hline DEU & 0.73 & 4.60 & 0.65 & 6.19 & 1.70 & 3.35 & 0.82 & 4.52 & 0.60 & 6.92 & 0.80 & 4.95 & 1.71 & 3.03 \\
\hline IRL & 0.14 & 0.33 & 0.14 & 0.49 & 0.32 & 0.24 & 0.15 & 0.33 & 0.11 & 0.49 & 0.14 & 0.36 & 0.36 & 0.24 \\
\hline ITA & 0.35 & 1.22 & 0.33 & 1.71 & 0.82 & 0.91 & 0.40 & 1.23 & 0.30 & 1.89 & 0.43 & 1.47 & 0.86 & 0.83 \\
\hline LUX & 0.10 & 0.21 & 0.09 & 0.28 & 0.23 & 0.15 & 0.11 & 0.20 & 0.08 & 0.31 & 0.11 & 0.23 & 0.24 & 0.14 \\
\hline NLD & 0.45 & 2.15 & 0.46 & 3.26 & 1.08 & 1.57 & 0.52 & 2.16 & 0.37 & 3.28 & 0.49 & 2.32 & 1.16 & 1.53 \\
\hline PRT & 0.14 & 0.38 & 0.14 & 0.53 & 0.34 & 0.28 & 0.17 & 0.38 & 0.12 & 0.58 & 0.16 & 0.42 & 0.36 & 0.26 \\
\hline ESP & 0.26 & 1.16 & 0.25 & 1.65 & 0.61 & 0.86 & 0.30 & 1.16 & 0.21 & 1.78 & 0.29 & 1.29 & 0.66 & 0.80 \\
\hline GRC & 0.09 & 0.22 & 0.09 & 0.32 & 0.21 & 0.17 & 0.10 & 0.22 & 0.07 & 0.34 & 0.10 & 0.25 & 0.22 & 0.15 \\
\hline
\end{tabular}

Notes: This table presents the cumulative impulse response in 24 months ahead of country in column to a shock originated in country in row. Country code: AUT: Austria, BEL: Belgium, FIN: Finland, FRA: France, DEU: Germany, GRC: Greece, IRL: Ireland, ITA: Italia, LUX: Luxembourg, NLD: Netherlands, PRT: Portugal, ESP: Spain, EST: Estonia, HUN: Hungary, LTU: Lithuania, POL: Poland, CZE: Republic Czech, SVK: Slovakia, SVN: Slovenia. 